DOI 10.37882/2223-2982.2020.04-2.24

\title{
ИНОСТРАННЫЕ ОБОЗРЕВАТЕЛИ О РУССКИХ РЕВОЛЮЦИОНЕРАХ НА СТРАНИЦАХ УРАЛЬСКОЙ ПРЕССЫ В 1905-1907 ГГ.
}

\section{FOREIGN OBSERVERS ABOUT RUSSIAN REVOLUTIONARIES ON THE PAGES OF THE URAL PRESS IN 1905-1907}

\section{A. Leontieva}

Summary: The article is devoted to the analysis of the political views of foreign observers against Russian revolutionaries on the pages of the Ural periodic press 1905-1907. The author concludes that foreign States were very wary of the Russian revolutionaries, tried to protect the masses from them, prevented entry into their territory, considered the revolutionaries murderers, robbers, rebels. European states feared that their people would not fall under the influence of Russian revolutionaries.

Keywords: Revolution, revolutionaries, Russian emigrants, socialists, foreigners, periodical printing, anarchy, revolutionary terror, Ural, Western Europe.
$\mathrm{H}$ а протяжении десятилетий не спадает интерес исследователей к истории революционного движения в России. Противники революционного движения активно опубликовывали на страницах Уральской периодики воззрения иностранных обозревателей на события революции 1905-1907 гг. В них правые элементы искали поддержку своих политических взглядов и методов, используемых в борьбе с социалистами. Сами же революционеры представляли себя в исключительно положительном образе, рекламировали себя в качестве борцов за свободу и социальную справедливость.

Изучая мнения иностранных обозревателей, можно утверждать, что русская революция 1905-1907 гг. оказывала большое влияние на множество государств и вынуждала их правительства остерегаться русских революционеров. В статье «Иностранцы и русская революция» в 1906 г. описывалось, что в отношении иностранцев к русской революции произошел определенный перелом: «сочувствие сменилось недоумением перед бессмысленным разрушением русскими революционерами своего Отечества. Затем, когда революционеры эмигрировали за границу, полным разочарованием и опасениями за свою собственную безопасность». [1] Многие государства принимали меры против русских революционеров и выдворяли их, как опасных полити-

\author{
Леонтьева Анна Алексеевна \\ К.и.н., Трехгорный технологический институт - филиал \\ ФГАОУВО «Национальный исследовательский ядерный \\ университет «МИФИ» \\ Baeva.ania2011@yandex.ru
}

Аннотация: Статья посвящена анализу политических взглядов иностранных обозревателей в отношении русских революционеров на страницах уральской периодической печати 1905-1907 гг. Автор приходит к выводу о том, что иностранные государства очень настороженно относились к русским революционерам, старались оградить народные массы от них, не допускали проникновения на свою территорию, считали революционеров убийцами, грабителями, мятежниками. Европейские государства опасались, чтобы их народ не попал под влияние русских революционеров.

Ключевые слова: иностранцы, революция, революционеры, социалисты, периодическая печать, анархия, революционный террор, Урал, Западная Европа.

ческих рецидивистов.

В русских революционерах за границей видели деятелей не русской революции, а в принципе, революции ради революции, людей одинаково опасных как в России, так и за ее пределами. Эти опасения подтверждали и санкционировали сами левые политические силы своим руководящим участием в анархистских беспорядках, политических и социалистических демонстрациях и в уголовных преступлениях. Иностранцы придерживались мнения, что революционеры представляли огромную опасность для всех стран: «Русской революции - позорная слава!». [1]

Подобного рода настроения вынуждали германское правительство задерживать и высылать русских эмигрантов, несмотря на их протесты и ссылки на международное право, предоставлявшее политическим эмигрантам убежище в других странах. При этом принимались меры к недопущению их в высшие учебные заведения Германии, но в тоже время не отказывали в образовании иностранцам. К русским студентам относились с особой осмотрительностью, в виду их сомнительной политической благонадежности.

В венской газете «Fremdenblatt» было помещено 
несколько статей о «русских делах». Касаясь известий о подавлении революционного движения в Москве, «Fremdenblatt» на своих страницах писал о том, что московская революция не была восстанием народа. [2] По данным газеты, большие массы русского народа желали мирного прогресса, путь который был проложен министерством графа Витте, проводившим реформы. Революционеры не обращали внимание на настроения средних классов и на противоречия со стороны рабочих. Только гибель тысяч сторонников и недостаток вооруженных средств могли парализовать революционную деятельность. Но пока Россия не была освобождена от революции, о реформах можно было лишь составлять планы, проводить их в действительность было не возможно. Иностранцы были возмущены тем, что «как можно было совершать работу по организации выборов, пока в русских городах происходили мятежи? Как можно было создавать социальные реформы в пользу фабричных рабочих, когда во всей экономической деятельности застой. Разум русского народа задавал себе эти вопросы?» [2]

B «Gazecie Polskiej» был обозначен интересный факт о том, что варшавские газеты уделяли много внимания протестам против убийств, которые совершались под лозунгом революционного террора. Газета осуждала насильственные действия социалистов. Борьба, которую вели национал демократы с социалистами, не была безрезультатной, это доказывает следующая заметка: «На варшавских фабриках, в обеденное время не перестают появляться агитаторы от имени социалистических партий. Работа агитаторов за последнее время была бесплодна. Рабочие принимают их свистками и вышучиванием. На днях на одной из фабрик рабочие порвали квитанции по уплаченным взносам и заявили агитатору, что впредь в пользу социалистов ничего платить не будут». [3] В итоге рабочие люди пришли к выводу о том, что поскольку их лишают возможности работать, вовлекая в забастовки, то и платить социалистам незачем.

В «Пермских губернских ведомостях» в 1906 г. в статье «Заграница. Англия и русские революционеры» были описаны способы, при помощи которых Англия оберегала себя от русских революционеров. Во времена Уильяма Гладстона въезд иммигрантов в Англию был облегчен. Впоследствии возникали случаи нарушения чиновниками правил, которые были установлены для иммигрантов. Многим иммигрантам было отказано в праве въезда в Англию, несмотря на то, что они отвечали всем требованиям устава. Некоторые, из не допущенных утверждали, что были вынуждены оставить Россию по политическим причинам, но, были отправлены обратно. Другие из не допущенных вполне отвечали экономическим требованиям и могли представить пять фунтов, но все же не были впущены на том основании, что, по мнению чиновников, не могли бы найти в Англии заработка. Иммиграционный совет, в большинстве случаев, подтверждал постановление чиновников, которые заявляли владельцам судов, перевозящих иммигрантов, что «известные облегчительные инструкции министра Уильяма Гладстона являются не действительными и что впредь капитаны судов не должны принимать пассажиров, которые не могут предоставить пяти фунтов». [4]

В Англии в 1906 г. смотрели на русских людей как на опасных революционеров и анархистов, и, когда отголоски событий раздавались по всему миру, допущение русских иммигрантов, «зараженных революционным духом» [4], являлось нежелательным.

Таким образом, в западноевропейских политических сферах взгляд на русскую революцию и на ее представителей сильно изменился не в их пользу. Моральная беззастенчивость «освободителей» постепенно лишила их образа борцов за возвышенные принципы. Выясняющиеся постепенно политические и социальные взгляды русских революционеров демонстрировали «прочность между анархическими стремлениями, где присутствовало отрицание собственности, семьи, принципов власти и дисциплины - занимали первое место». [4] Следовательно, взгляды культурных людей Запада, которые привыкли ценить все выше перечисленные элементы, приобретенные трудом целых поколений, отвернулись от русских революционеров.

Сотрудник «La Petite Republique» Габриель Бертран объехавший всю Россию, впоследствии свидетельствовал о том, что если «сопоставить и координировать все факты, то можно заметить, что в России происходило страшное и грозное сражение». [5] Французские газеты множество раз выражали свое изумление тем фактом, что богатая буржуазия больших городов, профессора, адвокаты, врачи, инженеры относились благоприятно к народным движениям и присоединялись к стачкам.

По мнению иностранной печати, объединяло либеральные и социалистические элементы, интеллигентную буржуазию и народ - это стремление освободиться от самодержавного режима, обеспечить глубокие реформы и завоевать свободу. Иностранцы указывали на бедность русских рабочих и крестьян, но недостаточно подчеркивали, какой тяжестью давил на них абсолютизм. Все силы производства и труда объединялись, чтобы разрушить правительственные традиции. «Репрессии, убийства женщин и детей, произвольные расстрелы побудили всеобщее порицание: Россия разучилась быть почтительной». [5]

Рассматривая и анализируя множество фактов в отношении русских революционеров, складывается вывод о том, что Западная Европа относилась к русским социалистам очень сурово. Европейские государства не хотели пускать на свою территорию «политических бан- 
дитов» [6], которые могли внести с собой революцию, нарушить всеобщий покой, подвергнуть риску жизнь и имущество жителей. «Иностранцы не попадались на обман «социал-демократов» и считали, что под данным термином скрыто «убогое и дикое содержание». [6]

В рассматриваемый период Европа, в своих обращениях к русскому народу, советовала быть умнее и осторожнее: «Ваши социал-демократы не пророки, а нарушители покоя и благосостояния людей». [6] Иностранные современники не хотели оказывать русским людям гостеприимства, так как считали, что они его не заслужи- вали.

При анализе публикаций и воззрений иностранных обозревателей с уверенностью можно сказать, что они считали Россию очагом революционной смуты. Даже те государства (Великобритания, Франция, Швейцария), которые изначально поддерживали революционеров и считали их борцами за свободу, впоследствии кардинально изменили свое мнение на их счет. На Западе революционеры воспринимались безнравственными людьми, пытавшимися разорить Россию.

1. Вятский вестник. 1906. 16 августа. № 177.

ЛИТЕРАТУРА

2. Пермские губернские ведомости. 1906. 4 января. № 3.

3. Пермские губернские ведомости. 1906. 1 июля. № 141.

4. Пермские губернские ведомости. 1906. 10 августа. № 174.

5. Оренбургский листок. 1906. 12 февраля. № 34.

6. Уфимский край. 1907. 6 мая. № 99.

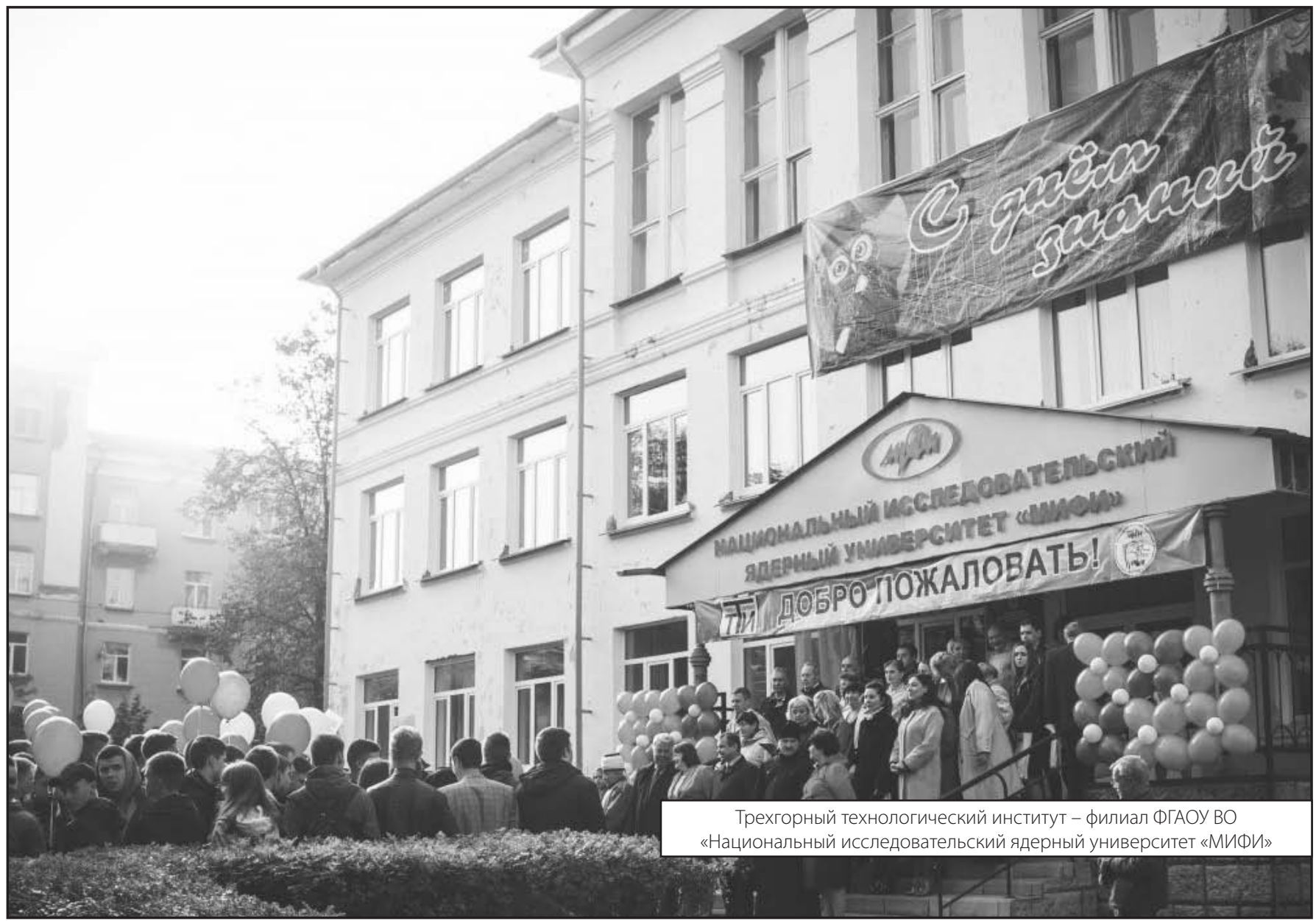

